\title{
ЮВІЛЁ̈
}

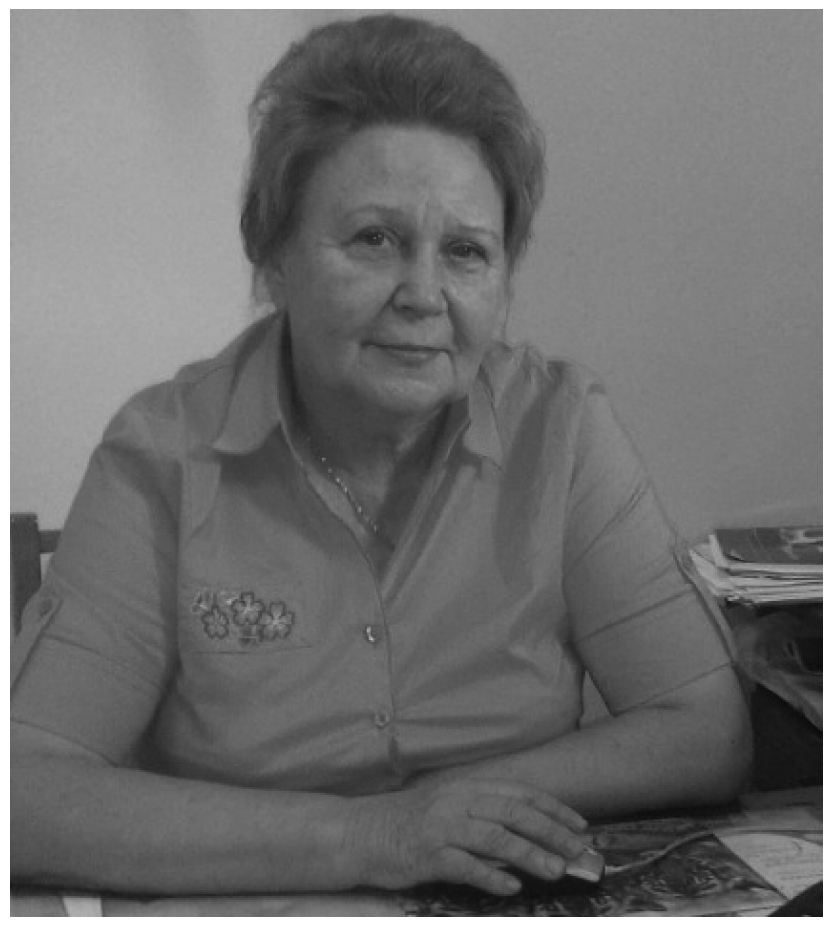

\section{ДУДІНА ОЛЕНА ОЛЕКСАНДРІВНА}

\author{
(до 75-річчя від дня народження)
}

Олена Олександрівна Дудіна народилася 10 червня 1940 р. на хуторі Волвенківському Ізюмського району Харківської області в селянській родині. Після закінчення Харківського медичного інституту у 1963 р. працювала лікарем-педіатром Центральної районної лікарні м. Барвінкове Харківської області, у 1966-1968 рр. - районним педіатром Московської районної лікарні Таджицької РСР, у 1968-1969 рр. - старшим інспектором МО3 Таджицької РСР, у 1970-1972 рр. - дільничним педіатром Дорожньої лікарні № 2 м. Києва.

У 1972-1974 рр. О.О. Дудіна працювала клінічним ординатором Київського медичного інституту ім. О.О. Богомольця. Після закінчення ординатури тимчасово працювала лікарем станції швидкої допомоги.

У 1975-1978 рр. - завідувач організаційнометодичного кабінету Київського науково-дослідного інституту педіатрії, акушерства і гінекології.

У 1978-1997 рр. - головний педіатр, заступник начальника з охорони материнства і дитинства Головного управління охорони здоров'я Київської міської державної адміністрації.

З 1997 р. і дотепер Олена Олександрівна працює у ДУ «Український інститут стратегічних досліджень МОЗ України». Дудіна О.О. - старший науковий співробітник за спеціальністю «Соціальна медицина», завідувач відділення охорони здоров'я матері і дитини.

У 1984 р. О.О. Дудіна захистила дисертацію на здобуття вченого ступеня кандидата медичних наук на тему «Клініко-лабораторні особливості та питання реабілітації дітей, які перенесли у ранньому віці стафрілококові захворювання».

Дудіна О.О. розробила і впровадила в практику роботи педіатричної служби принципово нову функціонально-структурну модель дитячої поліклініки в умовах переходу до сімейної медицини та довела ії ефективність. Розробила оригінальну методику визначення фрункцій сімейного лікаря з надання медичної допомоги акушерсько-гінекологічного і педіатричного профрілю, методику регіональної рейтингової оцінки стану здоров'я жінок і дітей та діяльності акушерсько-гінекологічної служби, рейтингової оцінки діяльності дитячих обласних лікарень, систему моніторингу та оцінки регіоналізації перинатальної допомоги.

Олена Олександрівна однією з перших у нашій країні почала займатися питаннями обґрунтування і забезпечення переорієнтації діяльності акушерсько-педіатричної служби на засади доказової медицини, є національним тренером із цих питань, проводить тренінги «Теорія і практика доказової медицини», бере участь у розробці національних клінічних протоколів, медико-організаційні технології яких ґрунтуються на даних надійних досліджень. За безпосередньої участі Олени Олександрівни розроблена методологія і здійснена оцінка ефективності впровадження науково обґрунтованої практики в діяльність закладів охорони здоров'я акушерсько-педіатричної служби.

Олена Олександрівна - лікар вищої категорії з педіатрії та організації охорони здоров'я, заслужений лікар України, відмінник охорони здоров'я та цивільної оборони, нагороджена Почесною Грамотою Президії Верховної Ради України, почесними грамотами МОЗ України.

Вона має понад 230 публікацій, у т.ч. є співавтором 27 монографій, наукових посібників, численних нормативно-правових та директивних документів державного і галузевого рівнів.

Вельмишановна Олено Олександрівно, з нагоди ювілею прийміть наші найщиріші вітання та дозвольте побажати міцного здоров'я, миру і затишку у Вашій оселі та довгих років щасливого життя і плідної праці на благо нашої держави!

3 повагою колектив ДУ «Український інститут стратегічних досліджень МОЗ України», редакція журналу, друзі, учні та колеги. 